\title{
ASBESTOS PROPERTY DAMAGE SETTLEMENT IN A BANKRUPTCY SETTING
}

\author{
Robert B. MCKay*
}

I

\section{INTRODUCTION}

Asbestos is a fear-laden word. The costs, in terms of the personal tragedies of death or incapacitation as well as the extensive remedial costs of removing or shielding the offending substance, are virtually unparalleled by other toxic substances to which our society has unwittingly been exposed. ${ }^{1}$ The dangers of other toxic substances and potentially dangerous devices such as Agent Orange, intrauterine devices, and DDT have been recognized, but asbestos leads the list of horrors in the public mind.

Others in this symposium discuss various efforts to deal with the personal injury aspects of mass disasters through claims resolution facilities designed to bypass the judicial system. This article reports the ongoing efforts to compensate individuals and entities with property damage complaints against the largest former producer of asbestos, Manville Corporation.

An irony exists in the Manville situation. The enormous death and personal injury claims against Manville, ${ }^{2}$ which could rise to more than $\$ 3$ billion dollars, are multiplied several times over by the property damage claims. However, payment of the property claims will amount to no more than a fraction of the asserted claims. Those who drafted the Manville bankruptcy plan, on which all claims against Manville depend, carefully provided that the great bulk of the assets be set aside principally for payment of personal injury claims. Although compensation for property damage is important, American societal values suggest that property claims must be subordinated to personal injury claims when the assets available for restitution are limited.

The general contours of the asbestos tragedy are well known. The problem originated many decades ago but became rooted most firmly after

Copyright (C) 1990 by Law and Contemporary Problems

- Professor of Law, New York University School of Law.

1. Long after the abandonment of the use of asbestos in building construction, the potent fear of asbestos resurfaced with four accidents in New York City, the toxic force of which required the closing of both an apartment building and contaminated streets. David Pitt, Midtown Steam Pipe Bursts; Asbestos Is Released, NY Times B3 (September 26, 1989).

2. For a discussion of the mass resolution of the Manville personal injury claims, see Marianna S. Smith, Resolving Asbestos Claims: The Manville Personal Injury Settlement Trust, 53 L \& Contemp Probs 27 (Autumn 1990). 
World War II when asbestos was extensively used in shipbuilding and in the construction of private and public buildings. For present purposes, the questions are these: What was done to compensate for the almost incalculable losses? Has the compensation arrangement worked as planned? What lessons do these efforts suggest for the future, which we cannot be confident will be free of other disasters? In an attempt to answer these questions, it is time to review the actions taken in resolving the Manville property damage claims and to evaluate the potential for achievement of the goals of the bankruptcy reorganization plan.

\section{II}

\section{The Bankruptcy Plan}

It is not relevant to this discussion to judge the motivation of Manville, when in 1982 it sought to discharge all personal injury and property damage claims through bankruptcy. It is sufficient to know that these claims, in the absence of bankruptcy, would have caused dissolution of the company after compensation to only the early claimants. It follows that the decision to seek protection against creditors through bankruptcy worked to the advantage of future claimants. The bankruptcy plan of reorganization had at least the concurrence of the representatives of personal injury and property damage claimants.

When Manville filed for chapter 11 protection in August 1982, the company faced approximately 16,500 personal injury suits with approximately 425 new cases being filed each month. ${ }^{3}$ The complex settlement negotiations were not completed until August 22, 1986. Bankruptcy Judge Burton Lifland of the Southern District of New York disclosed the plan of reorganization for Manville Corporation in an inch-thick document that included voting instructions for creditors and other claimants, a recounting of the negotiations leading to the plan, and a detailed analysis of the plan itself. ${ }^{4}$ Although opposed by certain creditor classes, the plan was approved by the requisite majority and declared effective before the end of 1986 . To justify the reorganization plan, the order stated:

In 1981, Manville, because of the insurance litigation, commissioned an epidemiological study to estimate the potential future incidence of asbestos-related disease cases. On the basis of that study, using conservative assumptions favorable to Manville, Manville projected that the aggregate liability for asbestos health claims which would be filed against it and the costs of disposing of those claims through conventional tort litigation through the year 2001 would be at least $\$ 1.9$ billion. Under generally accepted accounting principles applicable to Manville, having determined an aggregate liability in this amount Manville would be required to record that liability on its financial statements. The creation of this reserve would have essentially eliminated Manville's net worth and would have enabled lenders to accelerate substantially all of Manville's medium-term and long-term debt. It is

3. First Amended Disclosure Statement, Manville Corporation Second Amended and Restated Plan of Reorganization and Related Documents M-28 (Bankr SD NY August 22, 1986) ("Second Amended Plan").

4. Id. 
doubtful that Manville could have continued operating for long in the circumstances, and it is practically certain the prospects for asbestos health plaintiffs' recoveries would have been significantly diminished. ${ }^{5}$

The court's concern for the personal injury claimants triggered the plan. The court identified the need to protect Manville against dissolution, which could result from the claims of creditors, early-filing health claimants, and the high costs of litigation. The court was secondarily concerned for property damage claimants:

In addition, representatives of Claimants seeking damages against the Debtors ${ }^{|6|}$ on account of asbestos and asbestos-containing products present in various buildings, including unofficial committees representing schools, hospitals and universities and certain state attorneys general and city attorneys on behalf of their states and cities, have been actively participating in the reorganization proceedings but not as official committees. ${ }^{7}$

The central feature of the bankruptcy plan established two trusts, one for health claims-the Manville Personal Injury Settlement Trust ("the PI Trust") ${ }^{8}$-and one for property damage claims-the Manville Property Damage Settlement Trust ("the PD Trust"). It is important to note the structural similarities of the two trusts and their interrelatedness. Both trusts use claims resolution facilities designed to settle the numerous claims against Manville through the use of specified alternative dispute resolution mechanisms. The funding of the two trusts gives rise to their interrelatedness. The PI Trust is generally accorded priority of funding. According to estimates at the time of filing the reorganization plan, the PI Trust will receive about $\$ 2.5$ billion over a twenty-six-year period. ${ }^{9}$ The PD Trust, in contrast, will receive in the foreseeable future only a fraction of that amount, which can provide payment of at best a fraction of allowable claims. ${ }^{10}$

The August 1986 plan of reorganization ("the Plan") designated the following as trustees: Thomas F. Eagleton (United States Senator from Missouri for eighteen years until retirement on January 2, 1987); Daniel Reid Weedon, Jr. (a senior vice president of Arthur D. Little, Inc., in Cambridge, Massachusetts); and this author, Robert B. McKay (professor of law at New York University School of Law). $"$ The Plan also provided for funding of the PD Trust, effective as of the consummation date of November 28, 1988, in several ways: (1) payment by the debtor, Manville, of $\$ 100$ million in cash; (2) transfer by the PI Trust on consummation of $\$ 25$ million plus interest from

5. Id at $\mathrm{M}-28, \mathrm{M}-29$.

6. Technically, the plural "debtors" is appropriate because Johns-Manville Corporation, the predecessor in interest of Manville Corporation, and fourteen subsidiaries are parties to the Second Amended Plan. In subsequent discussion, this article will refer to these entities collectively as the "debtor."

7. Id at $\mathbf{M}-30$.

8. See generally Smith, 53 L \& Contemp Probs 27 (cited in note 2).

9. Cynthia Mitchell, Manville Concludes Plan to Settle Claims of Property Damage Linked to Asbestos, Wall St J 14 (August 25, 1986).

10. In August 1986, The Wall Street Journal estimated property damage claims at $\$ 89$ billion. While that figure may be high, it is clear that the property damage claims will exceed the personal injury claims by billions of dollars. See id.

11. Second Amended Plan at M-71 to M-75, M-227 to M-282 (cited in note 3). 
July 1, 1987; (3) receipt of insurance recovery proceeds in excess of $\$ 615$ million, ${ }^{12}$ which had been committed to the PI Trust, less Manville's postconsummation litigation costs; ${ }^{13}$ (4) receipt of unused PI Trust monies made available to it under the Plan (estimated to be at least $\$ 2.5$ billion); and (5) receipt of 20 percent of Manville's profits each year after all personal injury claims have been paid in full, if ever, which seems increasingly unlikely. ${ }^{14}$

The Plan provides that the PD Trust is irrevocable, but will terminate either after all property claims have been "liquidated and paid in full, and twenty-four consecutive months have elapsed during which no Property Claim has been filed with the PD Trust," 15 or when Manville and the PD trustees agree to termination upon Manville's procuring insurance coverage for outstanding claims. These conditions for termination are unlikely to be satisfied in the immediate future. The PD Trust will likely continue well into the twenty-first century.

\section{A. The PD Claims Resolution Facility}

The Plan provides for the creation of the PD Claims Resolution Facility for the determination and payment of property damage claims that meet the guidelines established by the Plan. The guidelines contemplate a no-fault, no-product-identification reimbursement for specified expenses made by eligible claimants because of asbestos-containing materials located in buildings. Punitive damages are not recoverable. The recoverable costs and the formula for compensation are as follows: eligible claimants will be compensated, without regard to product type, at 12 percent of the allowed cost for abatement of asbestos-containing surface treatments, 32 percent of the allowed cost for abatement of all other asbestos-containing material, and 20 percent of the allowed cost of survey, and operation and maintenance ("O\&M") costs.

Three qualifications are relevant to this schedule of payments. First, in the words of the Plan, "Since it is likely that payment of many Property Claims may be delayed, the amounts due will be adjusted by an inflation factor until payment is made. However, there will be no interest paid or accrued in any Property Claim." 16 Second, the designated percentage payments will be

12. By the time the Plan was announced in August 1986, Manville had reached settlement agreements with its insurers providing for approximately $\$ 505$ million. Manville continued negotiations and litigation with other insurers for additional insurance proceeds. As of early 1990 , the total insurance proceeds exceeded $\$ 750$ million. Id at M-72.

13. The most optimistic estimate of assets available to the PD Trust in its first several years of operation is about $\$ 300$ million. Annual Report and Financial Statements and Account of the Trustees of the Manville Property Damage Settlement Trust 11 (Bankr SD NY 1989) ("1989 Annual Report').

14. The likelihood of the PD Trust's receipt of additional funds "not required" by the PI Trust is remote. The PI Trust revealed that in 1990 it could run out of cash to pay asbestos victims and might have to sell stock to cover the gap. A determination that all personal injury claims have been satisfied could not possibly occur for many years. Sandra Atchison, Just When Manville Thought It Was Safe ... . Business Week 36 (November 20, 1989).

15. Second Amended Plan at M-231 (cited in note 3). Manifestly, this condition will not be met.

16. Id at M-74. 
further reduced because the amount payable in each cycle (a term to be explained below) will include only funds available in that cycle as a fraction of the claims allowed. ${ }^{17}$ It is evident that in the first cycle there will be insufficient funds to pay the full amount of the allowable claims. Undoubtedly some potential claimants decided against filing because the likely return seemed not to be worth the trouble of assembling the documentation required for filing. ${ }^{18}$ Third, the Plan gives priority of payment to abatement of asbestos insulation and surface treatments.

Each property damage claim filed with the facility is reviewed to determine allowability in accordance with the standards set forth in the guidelines. The reduction formulas determine the amount payable on each claim, which is to be paid within a specified period of time. The facility first reconsiders any payment dispute. Then, if the proposed payment remains unacceptable to the claimant, the claim is subjected to binding arbitration. ${ }^{19}$ Resort to tort or other litigation is not an option.

Litigation challenging various aspects of the Plan ended when the United States Supreme Court denied review of the Second Circuit decision upholding the Plan. ${ }^{20}$ The Plan took effect thirty days later. This article summarizes the events occurring in the management of the PD Trust in the ensuing twenty-seven months. ${ }^{21}$

First, the trustees selected key staff members who would provide technical expertise, and organize and staff the facility. After a careful search, the trustees appointed George A. Davidson of Hughes Hubbard \& Reed as counsel, and Kurt $\mathrm{H}$. Schaffir as executive director. The performance of both men have more than fulfilled the trustees' expectations. George Davidson and his colleagues at Hughes Hubbard have provided sound advice in interpretation of the sometimes less than clear language of the Plan, the intricacies of bankruptcy law, the procedures for maximizing the collection of insurance funds owed to Manville, and the myriad problems involved in organizing a substantial enterprise.

Kurt Schaffir recommended the selection of Vincent P. Blake as secretarytreasurer, another successful appointment. The Trust staff opened a small headquarters office in Greenwich, Connecticut, which has since moved to White Plains, New York. Kurt Schaffir and Vincent Blake successfully

17. Id. Moreover, since abatement claims are given a priority, it appears unlikely that survey and O\&M expenses will be reimbursed in the foreseeable future. Id at M-251.

18. The original estimate of claims likely to be filed in the first cycle was at least 50,000 . In fact, only 16,800 were filed by the close of the first-cycle filing period on October 31, 1989.1989 Annual Report at 1 (cited in note 13 ).

19. The contract for the development of procedures for initial mediation and binding arbitration of disputes was awarded to the New York office of Endispute, an organization involved in the establishment of alternative dispute resolution procedures. Michael D. Young, the director of the New York office, selected mediators and arbitrators and provided training for them.

20. MacArthur Co. v Johns-Manville Corp., 488 US 868, den rev, 837 F2d 89 (2d Cir 1988).

21. This summary is provided by the Interim Report to the Court of the Trustees of the Manville Property Damage Settlement Trust for Period from Appointment to Consummation and Annual Report for Period from Consummation to December 31, 1988 (Bankr SD NY, filed February 27, 1989) ("Interim Report"). 
negotiated with Arthur Young \& Company to serve as independent accountants and Manufacturers Hanover to serve as investment managers. The parties drew plans for the facility itself and arranged with Andersen Consulting of Arthur Andersen \& Company to design, install, and operate the required data processing system at their Stamford, Connecticut location. Adjustco, Inc., agreed to review all claims and to conduct the actual dispute resolution work at the White Plains location. The trustees selected May 1, 1989 , as the date to commence processing claims. The facility met this goal by mailing all claim forms in April 1989. Potential claimants were advised that eligibility for payment from first cycle funds required filing between May 1 and October 31, 1989.

Not surprisingly, because the Plan had been drafted in the absence of any relevant models, problems arose in the development of the new operation. However, the facility overcame principal difficulties, both expected and unexpected, and became fully operational in time to receive the first claims filed on May. 1, 1989. ${ }^{22}$

\section{B. Guidelines for Payment}

The Plan gives the PD Claims Facility the responsibility of providing " the exclusive method for allowance and payment of asbestos related Property Damage Claims." 23 Since the Plan provides the exclusive alternative to litigation and other dispute resolution mechanisms, it is appropriate that the payment process is described in considerable detail. ${ }^{24}$ The following paragraphs provide the essence of the directions outlined in the Plan.

The Plan divides the processing and payment of property claims into selfcontained cycles. The first cycle lasted six months, concluding on October 31 , 1989. The second cycle commenced on November 1, 1989, for a twelvemonth period ending October 31, 1990, with the third and fourth cycles following with similar twelve-month periods. All claims filed within each cycle are "deemed to have been filed on the same day," and payments within each cycle are to be processed promptly and paid within 120 days following

22. See Report to the Court on Operations of the Manville Property Damage Settlement Trust for the Second Quarter of 1989 (Bankr SD NY, filed July 25, 1989). It is appropriate to note that the apparently successful initiation of the PD Trust is attributable in large part to the spirit of enterprise and cooperation that pervaded the effort of all participants. During 1987 and 1988, the trustees met almost every month, sometimes more frequently, particularly during the period in which key staff personnel were selected. With the retention of George Davidson as counsel in May 1987 and Kurt Schaffir in January 1988, the operation began to take its mature shape. Throughout this process, it is important to acknowledge the unfailing helpfulness of key officials of Manville, particularly George Dillon, chairman of the board; Richard Von Wald, general counsel; and Herbert Edelman, outside counsel. They frequently attended trustee meetings and were always available for advice. Similarly, the claimants' representatives, ever watchful over the interests of schools, hospitals, universities, and state and local governments, frequently met with trustees and staff in usually successful efforts to reach agreement on matters that might otherwise have resulted in dispute and delay.

23. Second Amended Plan at M-250 (cited in note 3).

24. Id at $\mathrm{M}-250$ to $\mathrm{M}-252$ (detailing the allowance procedures and distribution guidelines). 
completion of the cycle, except where final allowance cannot be completed before the end of the cycle. ${ }^{25}$

All claimants must submit the supporting documentation specified in the distributed claim forms. Although property damage claimants are invited to seek reimbursement of money spent for abatement, survey, and O\&M costs in any cycle, the Plan provides that all abatement claims must be paid to the full extent allowable before any payments can be made for survey or O\&M expenditures. Thus, the Plan assures the abatement claimants who do not receive full payment of their allowable claim within a single cycle that they will receive their ratable share of the balance due in each succeeding cycle until the entire allowable amount has been paid. In view of the limited funds available in the first cycle, even with the potential to be increased later, it is impossible to offer hope that any payments will be made in this century on survey and O\&M claims, or very possibly ever. ${ }^{26}$

\section{Claims and Claimants}

Unlike the PI Trust guidelines, which provide relief for future claimants ${ }^{27}$-individuals who had been exposed to asbestos but who had not filed a claim by the date of the bankruptcy order or even by the date of consummation-the PD Trust guidelines bar all property damage claims by claimants who had not filed with the bankruptcy court by a specified date in 1984. Accordingly, when the PD Trust commenced in late 1986, a finite list of potential claimants existed. ${ }^{28}$

25. Because the great bulk of the first-cycle claims was filed in the last few weeks before the cycle closed on October 21,1989 , it became necessary to petition the bankruptcy court for an extension of time for resolving claims, from 60 to 120 days after filing. Even with the addition of personnel to handle the sudden influx of claims, it was impossible to complete the processing of last-minute claims within the sixty days originally contemplated.

Additional problems arose in interpreting the Plan's language on payment dates. The Plan contemplated a single payment date at the end of each cycle to be made within 120 days of the closing of the cycle, which was March 1, 1990, for the first cycle. Since the Plan did not clarify the date by which the Trust was to compute the assets available for payment and the amounts to be reserved, it became necessary to ask the court for guidance. In addition, because processing of at least some claims might be completed as late as February 28, 1990, particularly those in which the initial allowance is disputed, and because it takes time to learn the precise amount of liquid assets on a given date, it became necessary to ask the court for an extension from fifteen to thirty days for the calculation of payable amounts.

26. In fact, with the possible exception of proceeds of insurance written by carriers in liquidation, it is anticipated that the PD Trust will have distributed virtually all resources likely to be available in this century by the conclusion of the fourth cycle in 1992, except for reserves maintained to assure operating expenses and indemnification for litigation expenses. Accordingly, to increase the amount available to pay claimants, the PD Trust petitioned the bankruptcy court for authorization to suspend operations after the fourth cycle until the infusion of new funds in the next century, thereby freeing a substantial portion of the reserves for current payments. Order Approving Temporary Suspension of Operations of PD Claims Resolution Facility for the Manville Property Damage Settlement Trust (Bankr SD NY January 18, 1990).

27. See Smith, $53 \mathrm{~L} \&$ Contemporary Problems at 27-28 (cited in note 2).

28. Disputes as to the allowability of certain individual claims and of some classes of claims have not been finally resolved. The unresolved disputes primarily involve the claimants and Manville, which had the right and responsibility to contest or accept proofs of claim filed with the bankruptcy court on which depended status as eligible claimants, leaving to the Trust the determination of the allowability of individual claims. 1989 Annual Keport at 7 (cited in note 13). 
In the spring of 1989 , after many months of review and revision, the claim forms for abatement, survey, and O\&M costs were finalized and mailed to all property damage claimants in the Manville bankruptcy who had requested forms. It is perhaps surprising that of the more than 9,000 original claimants on the Manville list, only 5,909 responded with a request for forms. ${ }^{29}$ By October 31, 1989, 2,636 of the original claimants had filed 16,800 individual abatement claims and 3,275 survey and O\&M claims.

In November, 1989, after receipt of all first-cycle claims (but with processing completed only for a small number), the Trust staff estimated that total claims would equal about $\$ 1.5$ billion, resulting in payment, if all claims were fully allowed, of about $\$ 300$ million. The staff assumed disallowance of about 10 percent; consequently, the $\$ 100$ million dollars estimated to be available for payment in the first cycle would result in about a 40 percent payout. ${ }^{30}$

\section{Available Funds}

The central objective of the PD trustees continues to be the minimization of administrative costs to conserve the limited assets for claimant payments. In keeping with this policy, the principal costs during the start-up period (roughly January 1987 through April 1989) were the fees and expenses of the contractor for the design and installation of the claims system and the data processing operations. ${ }^{31}$

\section{III}

\section{Conclusion}

It is too early to draw conclusions about the ultimate success of the PD Trust. Nevertheless, this much can be said: the bankruptcy plan attained its principal goals of (1) assuring payment to personal injury claimants, present and future, that might otherwise have been denied, as well as at least partial compensation to property damage claimants, and (2) avoiding the almost certain destruction of a viable company. Manville has emerged from its asbestos ashes into the economic sunlight of profitability.

29. Approximately 3,000 putative claimants also assert a right to file on the basis of proofs of claim filed as a class action. Manville disputes this right, but the issue has not been resolved as of this writing. Approximately 575 affiliates and 1,006 class action claimants requested forms. Id at 12-15.

30. All these figures are estimates that will undoubtedly require some adjustment upon final determination. These calculations also do not include the disputed class action claims or certain other adjustments that have been agreed to but not calculated. Approval of the class action claims is estimated to reduce the payout to about $50 \%$. The other adjustments will not have a material effect on payout percentages. Report to the Court on Operations of the Manville Property Damage Settlement Trust for the First Quarter of 1990 (Bankr SD NY April 30, 1990).

31. Directors' and officers' liability insurance was an unexpectedly large expense. The trustees did not consider their activities as high risk since these activities involved no more than watchful attention to the reimbursement process. However, the dread word, asbestos, sharply limited the willingness of insurance companies to bid coverage and escalated the premium beyond expectations. Interim Report at 30-32 (cited in note 21 ). 
Despite these successes, the exquisitely detailed provisions of the Plan have presented many problems of interpretation and implementation. While it is not possible to expect fine-tuned prescience on the part of the drafters of such an instrument, particularly where there may be conflicting interests, one hopes that future instruments will permit more discretion to those destined to experience the reality of circumstances that were unpredictable at the time of drafting. 


\section{APPENDIX \\ An Afterword to Professor McKay's Article}

Professor Robert B. McKay, author of the accompanying article and former Chair of the Manville Property Damage Settlement Trust, died in July 1990. This update was written in May 1991 to summarize subsequent developments in claims processing and payment, asset collection, legal proceedings, and restructuring."

\section{Claims Processing and Payment}

The second cycle of claims processing and payment for the PD Trust ended October 31, 1990. An additional 7,789 claims were filed during that period, bringing the total to more than 24,000.' By February 28, 1991, the deadline for fixing payments, the PD Trust processed 7,510 of the secondcycle claims. Of the remaining second-cycle claims, 260 had received notices of disallowance by that date and were awaiting a response; 19 were in reconsideration. The aggregate "payable" amount for the first two cycles, excluding the putative class action claims, exceeded $\$ 290$ million.

In March of 1991, after allowance for reserves for claims of putative class members (claimants who had sought to satisfy the bar date in bankruptcy by relying on a class action proof of claim rather than on individual proofs of claim) and other requisite reserves, approximately $\$ 55$ million was available for payment. Out of this sum, holders of first-cycle claims who had received initial payment in March 1990 received $\$ 24$ million, holders of first-cycle claims resolved after March 1990 received $\$ 15$ million, and holders of secondcycle claims received $\$ 16.4$ million. This brought amounts paid to 64 percent of payable amounts for first-cycle claims and 18 percent of payable amounts for second-cycle claims. ${ }^{2}$

It is expected that first-cycle claimants will receive more than 80 percent of the payable amounts of allowed claims by the end of the fourth cycle. This is a considerably higher percentage than originally expected. ${ }^{3}$

Copyright $\odot 1990$ by Law and Contemporary Problems

* George A. Davidson and Theodore V. H. Mayer of Hughes Hubbard \& Reed, New York, New York, authored the afterword.

Trustee D. Reid Weedon, Jr,, succeeded Professor McKay as Chairman of the PD Trust. Professor Arthur W. Murphy of Columbia University Law School filled the vacancy.

1. The majority of the second-cycle claimants also filed claims in the first cycle.

2. For a definition of "payable amounts," see Robert B. McKay, Asbestos Property Damage Settlement in a Bankruptcy Setting, 53 L \& Contemp Probs 37, 40-41 (Autumn 1990).

3. Under the formula established in the Claims Resolution Guidelines, the payable amount is either $32 \%$ or $12 \%$ of allowed abatement cosis, depending on the type of asbestos-containing material. Moreover, because they have a lower payment priority and there are insufficient funds to pay them, claims for survey, and operations and maintenance costs will not be processed by the PD trust. 


\section{Asset Collection}

As discussed by Professor McKay, ${ }^{4}$ the PD Trust received the right to collect on Manville's insurance coverage under certain conditions. Settlements yielding $\$ 4.2$ million have recently been reached with all but one of Manville's remaining solvent insurers. Litigation against the remaining solvent carrier, Canadian Indemnity Company, is pending.

Several carriers went into liquidation before paying anything on Manville's asbestos claims. The PD Trust has pressed claims against both the liquidators of these insurers and state insurance guaranty associations. The PD Trust has entered into settlement with the guaranty associations for $\$ 26$ million in ready funds. In addition, claims have recently been allowed by the liquidators of Transit Casualty Company in an amount exceeding $\$ 24$ million and claims by the liquidators of Midland Insurance Company are expected to be allowed for at least $\$ 44.25$ million. The amount to be distributed out of these two liquidations, as well as the schedule of distribution, is still uncertain.

While the impact of this insurance litigation and settlement activity on the asset figures cited by Professor McKay is palpable, it does not vary any of Professor McKay's conclusions due to the enormous magnitude of the potential liability.

\section{III}

\section{Legal Proceedings}

The decision mentioned by Professor McKay, ${ }^{5}$ which permitted the PD trustees to submit a plan for the suspension of claims processing operations following the fourth class allowance cycle, was affirmed by the United States Court of Appeals for the Second Circuit on November 26, 1990. Accordingly, in January 1991 the Trust distributed to holders of allowed first-cycle claims approximately $\$ 25$ million which had been held in reserve to cover expenses in the event the appellate court had reopened claims processing operations to continue beyond the fourth cycle. The trustees will file in July 1991 a proposed plan for suspension of claims processing operations after the fourth cycle.

The motion to expunge the proof of claims filed on behalf of putative classes of institutions, such as hospitals and universities, remains pending. With the approval of the Bankruptcy Court, the Trust has continued to process but not pay these claims, and to reserve funds to permit payment in the event Manville's motion is denied. Claims by these putative class members have amounted to 10 percent of the PD Trust's claims activity.

4. McKay, 53 L \& Contemp Probs at 40 (cited in note 2) (noting that the right is triggered after the Manville Personal Injury Settlement Trust receives $\$ 615$ million of the insurance proceeds).

5. See discussion id at note 26 . 
On April 16, 1991, the Bankruptcy Court approved the PD trustees' accounting for 1990 and entered an order discharging the trustees from liability for the matters referred to therein.

\section{IV}

\section{Restructuring of the Personal Injury Trust}

In connection with an effort to refinance and restructure the operations of the Manville Personal Injury Settlement Trust at the direction of the Chief Judge of the United States District Court for the Eastern District of New York, the PD trustees were asked to consent to certain transactions and an amended and restated version of the PD Supplemental Agreement. The trustees' consent, which is subject to contingencies including final approval of a class action settlement restructuring the PI Trust according to specified terms, will result in the following changes, among others:

(1) Manville's contingent obligation to pay to the PD Trust a cost-ofliving-adjusted $\$ 250,000$ annually over the life of the PD Trust will be converted to a certain obligation.

(2) The PD Trust's right to 20 percent of Manville's profits will be triggered by termination of the PI Trust, rather than by and to the extent of the PI Trust's ceasing to need such funds.

(3) The PD Trust will forfeit contingent rights, which, based on testimony and findings in the PI Trust proceedings in the United States District Court for the Eastern District of New York, appear to be utterly without value, to the Bond and Second Bond.

Both a proposed class action settlement that will substantially reduce the administrative and litigation expenses of the PI Trust (and therefore make less remote the happening of contingencies that would trigger the PD Trust's right to profit participation), and the restructuring of the $\$ 250,000$ obligation, led the PD trustees to consent to the transactions required to effect the restructuring. 